\title{
RETRACING THE POSITION OF SHARIA SCIENCE IN THE FORMULATION OF LAWS AND REGULATIONS
}

\author{
Syahrul Anwar', Aden Rosadi², Fauzan ${ }^{3}$ \\ 1, 2State Islamic University (UIN) Sunan Gunung Djati Bandung, Indonesia \\ Jl. AH. Nasution No 105 Cibiru Bandung \\ E-mail: syahrulanwar@uinsgd.ac.id, adenrosadi@uinsgd.ac.id \\ ${ }^{3}$ State Intitute for Islamic Studies (IAIN) Bengkulu, Indonesia \\ Jl. Raden Fatah, Air Sebakul, Bengkulu \\ E-mail: fauzan@iainbengkulu.ac.id
}

\begin{abstract}
This study tries to explain the efforts to retrace the position of Islamic science in the formulation of laws and regulations in Indonesia. As part of the implementation of Islamic law and the national legal sub-system, the position of sharia is particularly strategic and significant. The existence and position of sharia science lie not only in theoretical development through academic studies but also in practical terms which can provide its own colour in the formulation of laws and regulations in Indonesia. The implementation of sharia in life is not only an individual normative obligation, but also a collective responsibility that involves academics, legal practitioners, and the government. The position of sharia in forming laws and regulations theoretically and practically can be seen from three aspects, including substance, structure, and culture.
\end{abstract}

Keywords: sharia science; law and regulation; substance.

\begin{abstract}
Abstrak: Penelitian ini mencoba menjelaskan tentang upaya pelacakan kembali posisi ilmu syariah dalam pembentukan peraturan perundangan-undangan di Indonesia. Sebagai bagian dari implementasi hukum Islam dan sub-sistem hukum nasional, posisi ilmu syari'ah sangat strategis dan signifikan. Keberadaan dan posisi ilmu syariah bukan hanya terletak pada pengembangan teoritis melalui kajian akademik, tetapi juga secara praktis dapat memberikan warna tersendiri dalam pembentukan peraturan perundangan-undangan di Indonesia. Implementasi ilmu syariah dalam kehidupan, bukan hanya kewajiban individual yang bersifat normative saja, tetapi juga menjadi kewajiban kolektif yang melibatkan akademisi, praktisi hukum, maupun pemerintah. Dengan menggunakan metode deskiptif tekstual-interpretatif, penelitian ini menunjukkan bahwa secara teoritis dan praktis, posisi ilmu syariah dalam pembentukan peraturan perundang-undangan dapat dilihat dari tiga aspek, antara lain: substansi, struktur, dan kultur.
\end{abstract}

Kata Kunci: ilmu Syariah; peraturan perundang-undangan; substansi.

\section{Introduction}

Legal history which governs civilization in Indonesia began with customary law, and then it was followed by Islamic law and finally Western law. These three laws have different characteristics, and their position can improve existing laws in

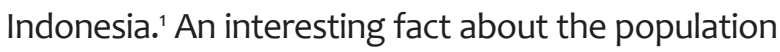
of Indonesia is that the majority of it is Muslims, but the legal system adheres to national law

${ }^{1}$ Muhammad Daud, "Kedudukan Hukum Islam Dalam Sistem Hukum Indonesia," Jurnal Hukum \& Pembangunan, vol. 12, no. 02 (1982), pp. 101-10. rather than Islamic law. ${ }^{2}$ The discourse on the dynamics and development of Islamic law in Indonesia based on three essential notes. ${ }^{3}$ First, the characteristics of Indonesian Islamic law are dominantly characterized by Arab personality (Arab oriented) and more closely attached to

${ }^{2}$ Muhammad Julijanto, "Implentasi Hukum Islam Di Indonesia Sebuah Perjuangan Politik Konstitusionalisme," in Annual International Conference Islamic Studies (AICIS XXI), (2012), pp. 66-85, http://www.republika.co.id/berita/dunia-islam/islammancanegara/12/05/09/m3qcqk-2030-.

${ }_{3}$ Mohammad Daud Ali, Pengantar Ilmu Hukum Dan Tatata Hukum Islam Di Indonesia, (Jakarta: PT Raja Grafindo Persada, 2007). 
the tradition of Shâfî̀ madhhab. This can be seen from the reference books used by the scholars who mostly employ the Shâfî figh books. Such conditions can also be seen in the formulation of the Compilation of Islamic Law formulated by Indonesian scholars who are particularly close to Shafi'i characteristic. Besides, methodologically most scholars use the books of figh written by Shafi'i madhhab scholars. As it is understood that most of the discussion of figh concept, primarily that is taught in most Islamic boarding schools, has only reached the issue of qiyâs, although there is something broader than that. ${ }^{4}$

Second, viewed from the material aspects of the substance (scope) of Islamic law developed in Indonesia, it seems to be more focused on private law or family law (ahwal al-syakhsiyyah), such as marriage, inheritance, waqf, as covered by the compilation of Islamic law (KHI). Until now, the Religious Courts Institution has only been authorized to handle cases relating to limited civil law (although there has been an increase in authority in the field of Sharia economics, but in practice, it cannot yet be handled by the Religious Courts). ${ }^{5}$ Indeed there is encouraging information that even though formally it cannot be applied, substantially the material contained in the new Criminal Code draft has adopted a lot of Islamic criminal law (jinayat). Another encouraging thing is the presence of Sharia banks and Baitul Mâl Wat Tamwil, as well as Sharia financial institutions in Indonesia today as the phenomenon of the existence of Islamic law in the field of muamalah. ${ }^{6}$

Third, judging from the aspect of enforcement, there seems to be a strong tendency that Islamic law is expected to be part of positive state law, as a form of government accommodation towards Muslims. If this tendency is correlated to the issue of legal effectiveness, there seems to be hope that by being appointed as state law, Islamic law will have a strong attachment to being adhered

${ }^{4}$ Mohammad Daud Ali, Hukum Islam PIH Dan THI Di Indonesia, (Jakarta: PT Raja Grafindo Persada, 1996).

${ }^{5}$ Aden Rosadi, Peradilan Agama Di Indonesia : Teori Dan Sistem Pembentukan, (Bandung: Simbiosa Reka Utama, 2015).

${ }^{6}$ Nurul Huda and Mohamad Heykal, Lembaga Keuangan Islam Tinjauan Teoritis Dan Praktis, (Jakarta: Kencana, 2010).

7 Aiman, "Kedudukan Ilmu Syariah Dalam PerundangUndangan," Aiman selalu berbagi, (2013), http://mamduhhakim. blogspot.com/2013/10/kedudukan-ilmu-syariah-dalam-perundang. html. to by the Muslim community. Such legal logic is temporarily acceptable, although in reality this is not always the case. There is a concern that the government will use these conditions to participate in determining which and what formulations of Islamic law to be implemented in Indonesia. ${ }^{8}$

Some of the reasons mentioned above are interesting and essential to study in completing scientific knowledge, especially in the field of law regarding the position of Sharia science in completing national law in Indonesia since Indonesia is building an ideal law for the people of Indonesia, including the development of the law that is based on the sharia science derived from the Quran and Hadith. ${ }^{9}$ Sharia science, which is the second gate in the formulation of law in Indonesia after customary law applied in Indonesian society, is the focus of the current study. ${ }^{10}$

\section{Method}

This study discussed normative aspects of sharia science tracking within regulations, and used textual-interpretative descriptive method. This method was used to seek a number of syariah related texts both in the Quran, Hadith, fiqih books, and history. In order to address the legislation aspect, it used taqnin method. It was used toseek the contribution opportunity of historic-normative sources for national legal products in Indonesia. Through this method, the author hoped to connect amount of information from previous studies with the theories in literature sources.

\section{Sharia science in legal theories approach}

The discussion about sharia cannot be seperated from in-depth understanding related to it. Sharia is related to the guidance in every area of life-based on Islamic principles of justice." Sharia science guides how we deal vertically to God and horizontally to humans $^{12}$. In the approach of jurisprudence, sharia

\footnotetext{
${ }^{8}$ Bahtiar Effendi, Islam Dan Negara: Transformasi Pemikiran Dan Praktik Politik Islam Di Indonesia, (Jakarta: Paramadina, 1998).

9 Sopyan Mei Utama, "Eksistensi Hukum Islam Dalam Peraturan Perundang-Undangan Di Indonesia," Jurnal Wawasan Yuridika, vol. 2, no. 1 (2018), p. 58, https://doi.org/10.25072/jwy. v2i1.166.

${ }^{10}$ Muhammad Daud, "Kedudukan Hukum Islam..., p. 11.

${ }^{11}$ Yussef Auf, "Islam and Sharia Law Historical, Constitutional, and Political Context in Egypt," Atlantic Council, no. 03 (2016), pp. 1-9.

${ }_{12}$ Christine Schirrmacher, The Sharia - Law and Order In (Germany: Hänssler Verlag, 2013).
} 
means obligations that must be followed by Muslims about how to deal with God, humans and objects according to the fundamental legal norms set by Allah Swt in the Quran and Hadith delivered by the Prophet. ${ }^{13}$ This means that our behaviors towards God, towards fellow human beings and towards objects have all been arranged so that humans do not get astray. Thus, humans as creatures created by God can benefit themselves and their environment. In the implementation aspect, sharia as a theoretical basis in the formulation of legislation uses a way of thinking based on two teachings considered as absolute truths, namely the teachings of the historical madhhab by Von Savigny and the decision theory of Ter Haar. ${ }^{14}$ In this case, Sunaryati Hartono has the opinion that at present, both opinions and theories are no longer reliable in an atmosphere of "planned" national development which indicates the formulation of our "national legal system". The theoretical basis used is as follows: ${ }^{15}$

First, the theory of Creed or syahadat, which is a continuation of the principle of monotheism in Islamic legal philosophy. The principle of monotheism requires every person who claims to have faith in Allah Swt to submit to Allah's commands while submitting to the Prophet and his sunnah. This theory is the same as the theory of legal authority explained by HAR Gibb, who states that Muslims who have accepted Islam must receive Islamic legal authority over themselves ${ }^{16}$. Second, the receptie exit theory. Hazarin created this theory. He argues that after the Proclamation of Indonesian Independence and the Establishment of the 1945 Constitution as the Republic of Indonesia Constitution, all Dutch East Indies regulations based on receptie theory no longer apply. ${ }^{17}$ Since this theory is precisely contrary to the spirit of the 1945 Constitution and besides it also contradicts the Quran and Sunnah, and contradicts Article 29 paragraphs 1 and 2 of the 1945 Constitution which states "The State is based on the divinity of the Almighty. And paragraph 2

${ }^{13}$ Nurhayati, "Memahami Konsep Syariah, Fikih, Hukum Dan Ushul Fikih," Jurnal Hukum Ekonomi Syariah, vol. 2, no. 2 (2018), pp. 124-34, https://doi.org/10.26618/j-hes.v2i2.1620.

${ }^{14}$ Edgar Bodenheimer, Jurisprudence: The Philosophy and Method of the Law, (Cambridge: Harvard University Press, 1967).

15 Pipin Sarifin and Dedah Jubaedah, Ilmu PerundangUndangan, (Bandung: Pustaka Setia, 2012).

${ }_{16}$ Juhaya S. Praja, Filsafat Hukum Islam, (Bandung: Pusat Penerbitan Universitas LPPM Universitas Islam Bandung, 1995).

17 Khoiruddin Buzama, "Pemberlakuan Teori-TeoriHukum Islam Di Indonesia,” AL-'ADALAH, vol. X, no. 4 (2012), pp. 467-72. states that "the State guarantees the freedom of the population to embrace their respective religions as well as to worship based on their respective religion and belief. Sayuti Thalib later developed this theory into the theory of receptio a contrasio. Third, the Recceptio a contrasio theory states that customary law applies to Muslims if it does not conflict with Islamic teachings. This theory also applies to Islam.

Based on the theories mentioned above, it can be concluded that Quran and legislation theory can be applied to the object of discussion in the form of laws and regulations relating to restructuring the legal system and legal politics in Indonesia based on the 1945 Constitution which includes the substance of the law, legal structure, and legal culture. Restructuring means reorganizing, correcting, and rearranging the general legal system.

\section{The Role of Sharia Science in the Formulation of Legislation}

The role of sharia studies in forming regulations can be divided into four forms..$^{18}$ First, in the sense that it is an integral part of Indonesian national law; Second, in the sense of being recognized for independence, strength and authority by national law and given status as national law; Third, in its function as a filter for Indonesian national legal materials; and Fourth, in the sense of being the main composition and element for the formulation of national law. Thus, it appears that Islamic law is an integral part of national law. Islamic law is a sub-system of the national legal system. ${ }^{19}$ As a subsystem, Islamic law is expected to make a dominant contribution to the development and renewal of national law that reflects the legal awareness of the Indonesian people. ${ }^{20}$ This is possible since the majority of Indonesia's populations are Muslims. The position of Islamic law in the post-independence Indonesian constitution, according to Ismail Sunny, is divided into two periods, ${ }^{21}$ namely: first, the period of

${ }^{18}$ M Muhtarom, "Kedudukan Peraturan PerundangUndangan Negara Dalam Institusi Hukum Islam," Jurnal Suhuf, vol. 27, no. Mei 2015 (2015), pp. 22-37.

${ }_{19}$ Mardani, "Hukum Islam Dalam Sistem Hukum Nasional," Jurnal Hukum \& Pembangunan, vol. 38, no. 2 (2008), p. 175, https://doi.org/10.21143/jhp.vol38.no2.170.

${ }^{20}$ Nasarudin Umar, "Konsep Hukum Modern: Suatu Perspektif Keindonesiaan, Integrasi Sistem Hukum Agama Dan Sistem Hukum Nasional," Walisongo: Jurnal Penelitian Sosial Keagamaan, vol. 22, no. 1 (2014), p. 157, https://doi.org/10.21580/ws.2014.22.1.263.

${ }^{21}$ Khalilullah Ahmas, "Hukum Islam Dalam Ketatanegaraan (Telaah Perspektif Menuju Indonesia Baru)," Jurnal Al-Syirah, vol. 1, no. 2 (2003), pp. 1-10. 
acceptance of Islamic law as a source of persuasion. Second, the period of acceptance of Islamic law as an authoritative source, that is, a source that has binding and legal power in Indonesian constitutional law. In subsequent developments, the Government of Indonesia rolled out legal political policies which within certain limits accommodated some of the wishes of Muslims.22

The contribution of the role of sharia sciences to the formulation of laws and regulations is part of the politics of law participation of Indonesian Muslim religious community within the democratic climate of Pancasila. Sharia enforcement through the state occurred in Indonesia is not a new agenda championed by Islamic political activists. ${ }^{23}$ Since the Constituent Assembly session in the 1950s, Indonesia's political map had narrowed to the Islamic and Nationalist groups. Later, Islamism became weaker, as a result of the emergence of Indonesian Islamic thinkers who were far more moderate and liberal. ${ }^{24}$

On the one hand, Islamic sharia positivation in the Indonesian legal system is the political success of Muslim political actors in achieving one of their political goals. ${ }^{25}$ This achievement can be seen from the shifting of antagonism of Islam and the state since the 1980 , until the reform era. This achievement manifests itself in the form of eroding the country's suspicions and developing state accommodation politics towards Indonesian Muslim communities. In connection with the laws and regulations, several laws and regulations based on sharia principles that are currently applied include. ${ }^{26}$

1. Law of the Republic of Indonesia No. 17 of 1999 concerning the Implementation of Hajj (State Gazette of the Republic of Indonesia No. 53, additionally State Gazette of the Republic of

${ }_{22}$ M Sularno, "Syari'at Islam Dan Upaya Pembentukan Hukum Positif Di Indonesia," Al-Mawarid, vol. 14, no. 2 (2006), pp. 211-19. Fauzan, "Progressive Law Paradigm in Islamic Family Law Renewal in Indonesia," Jurnal Ilmiah Mizani: Wacana Hukum, Ekonomi Dan Keagamaan vol. 7, no. 2 (2020). p. 187, https:// doi.org/10.29300/mzn.v7i2.3617.

${ }_{23}$ Muhammad Wahyuni Nafis and Rahman Zainuddin, Konstektualisasi Ajaran Islam, (Jakarta: Ikatan Persaudaraan Haji Indonesia, 1995).

${ }^{24}$ Ismail Hasani and A. Gani Abdullah, Pengantar Ilmu Perundang-Undangan, (Jakarta: . Fakultas Syar'ah dan Hukum UIN Syarif Hidayatullah, 2006).

${ }^{25}$ Masruhan, "Positivisasi Hukum Islam Di Indonesia," The Indonesian Journal of Islamic Family Law, vol. 01, no. 02 (2011): 214-17, https://doi.org/10.20885/unisia.vol26.iss48.art11.

${ }^{26}$ Pipin Sarifin and Dedah Jubaedah, Ilmu PerundangUndangan..., 2012.
Indonesia No. 3832) which was substituted with RI Law No. 13 Year 2008 concerning the Organization of Hajj (State Gazette of the Republic of Indonesia No. 60/2008, a supplement to Law of the Republic of Indonesia No. 4845).

2. Law of the Republic of Indonesia No. 38 of 1999 concerning zakat management (State Gazette of the Republic of IndonesiaYear 1999 No. 164, supplement to State Gazette of the Republic of Indonesia No. 3885).

3. Law of the Republic of Indonesia No. 7 of 1992 concerning banking, (State Gazette of the Republic of Indonesia Year 1992 No. 31, a supplement to State Gazette of the Republic of Indonesia No. 3472, as amended by Law of the Republic of Indonesia 1998 No. 182, a supplement to State Gazette of the Republic of Indonesia No. 3790).

4. Law of the Republic of Indonesia No. 23 of 1999 concerning Bank Indonesia (Statute Book of the Republic of Indonesia No. 66 of 1999, Supplement to State Gazette of the Republic of Indonesia No. 3843) as amended by Indonesian Law No. 3 Year 2004 (State Gazette of the Republic of Indonesia No. 7 Year 2004, supplement to State Gazette of the Republic of Indonesia No. 4357).

5. Law of the Republic of Indonesia No. 24 Year 2004 concerning deposit insurance institution (State Gazette of the Republic of Indonesia Year 2004 No. 96, supplement to State Gazette of the Republic of Indonesia No. 4420).

6. Law of the Republic of Indonesia No. 41 Year 2004 concerning waqf (State Gazette of the Republic of Indonesia Year 2004 No. 159, supplement to State Gazette No. 4459).

7. Law of the Republic of Indonesia No. 11 Year 2006 concerning Aceh Government (State Gazette of the Republic of Indonesia Year 2006 No. 62, supplement to State Gazette of the Republic of Indonesia No. 4633).

8. Law of the Republic of Indonesia No. 40 Year 2007 concerning limited liability companies (State Gazette of the Republic of Indonesia Year 2007 No. 106, supplement to State Gazette of the Republic of Indonesia No. 4756)

9. Law of the Republic of Indonesia No. 21 Year 2008 concerning sharia banking (State Gazette of the Republic of Indonesia Year 2008 No. 44, supplement to State Gazette of the Republic of Indonesia No. 4867). 
10. Law of the Republic of Indonesia No. 19 Year 2008 concerning state syari'ah securities (State Gazette of the Republic of Indonesia Year 2008 No. 7, supplement to State Gazette of the Republic of Indonesia No. 4852).

11. Presidential Instruction No. 1 Year 1991 concerning the compilation of Islamic law.

12. Qanun of Nangroe Aceh Darussalam Province No. 2 Year 2004 concerning the election of the Governor and Deputy Governor in the Province of Nangroe Aceh Darussalam as amended by the Qanun of Nangroe Aceh Darussalam Province No. 3 Year 2005 concerning amendment to Qanun of Nangroe Aceh Darussalam Province No. 2 Year 2004.

13. Law of the Republic of Indonesia No. 23 Year 2011 concerning Zakat Management (State Gazette of the Republic of Indonesia Year 2011 No. 115).

On the other hand, the Islamic sharia positivation becomes as if it were futile due to the discipline of Muslims, which showed no difference between before and after the positivation. Therefore, quoting from Arkoun, their main ideas remain imprisoned by regional and ethnographic images, their political articulation is still dominated by ideological and it needs to legitimize the regimes of society today. ${ }^{27}$ Descriptions recorded in the efforts to implement Islamic sharia in Aceh as well as in several other areas showed that the application of Islamic sharia was not only suffering from epistemological, political, but also sociological problems characterized by the cynicism of the manifesting society. For this reason, the choice of the role of sharia sciences in more productive laws and regulations must be formulated ${ }^{28}$.

Formalization of Islamic law in Indonesia is not an easy problem, at least it can be seen from two things. ${ }^{29}$ First, the objective conditions of a pluralistic Indonesian nation must be considered, not to cause counter-productive harm to Muslims themselves. Second, reformation on the conceptions, strategies and methods of the formulation of Islamic law,

${ }^{27}$ Mohammed Arkoun, The Concept of Authority in Islamic Thought: La Hukna Illa Li-Llah, (New York: Institute of Political science, 1984); Effendi, Islam Dan Negara: Transformasi Pemikiran Dan Praktik Politik Islam Di Indonesia.

${ }^{28}$ Ismail Hasani and A. Gani Abdullah, Pengantar IImu Perundang-Undangan..., 2006.

${ }^{29}$ Ashadi L. Diab, "Dinamika Pekiran Hukum Islam Di Indonesia Dan Tantangannya,” Jurnal Al-'Adl, vol. 8, no. 2 (2015), pp. 37-56. so that the resulting Islamic law does not conflict with the public's legal awareness and is following the characteristics of the national legal order that it aspires for. In connection with the second problem above, Islamic law in the context of national law is a law with its own character, namely as local Islamic law following ijtihâd and local conditions decided by valid lawmakers in Indonesia. Thus, practically Islamic law can differ from one country to another. Even so, Islamic law in various countries still comes from the same source, namely Islamic law as a divine law ${ }^{30}$.

Sharia (Islamic law) deserves to be a source of the formulation of national law, since it is considered capable of underlying and directing the dynamics of Indonesian society in achieving its goals. It contains a dimension rooted in the nas qath'i which is universal and applies for all time, besides it also includes a dimension rooted in the nas zanni as the area of ijtihâd and is adaptive to the times. There are four types of Islamic law reform products in Indonesia, namely: figh, fatwa, court products, and also laws and regulations. The big theme of the discourse of renewing Islamic legal thinking is derived from the term ijtihâd, which in the Indonesian context, the current ijtihâd movement shows a variety of methods and tendencies. Formalization of Islamic law in Indonesia faced several obstacles including the objective conditions of a pluralistic Indonesian which if not observed it can lead to counter-productive for Muslims themselves. Another obstacle was the difficulty of the formulation of the conceptions, strategies and methods of the Islamic law that did not conflict with public legal awareness and the characteristics of national law.

The term sharia democratic is basically used to facilitate the understanding of Islamic thought products that are based on critical, contextual, and historical studies. These products of thought generally aim to restore the spirit of fundamental Islam, which has been manipulated and reduced by classical Islamic thinkers and is conditioned in the form of sacred figh, and accepted by the Islamic community without exception. The product of thought and the basis on the principle of progressive revelation with a liberal interpretation is the meaning of democratic sharia. Democratic sharia is sharia that is acceptable within a social context ${ }^{31}$.

\footnotetext{
30 M Sularno, "Syari'at Islam Dan Upaya..., p. 20.

${ }^{31}$ Ismail Hasani and A. Gani Abdullah, Pengantar Ilmu Perundang-Undangan..., 2006.
} 
According to Yusril Ihza Mahendra's speech on the seminar at State Islamic University (UIN) Syarif Hidayatullah Jakarta, in Indonesia, Islamic law is actually a law that lives, develops, known and partly obeyed by Muslims in this country. How is the validity of Islamic law? When we look at the laws in the field of worship, then practically the Islamic law applies without the need to elevate it into positive legal principles, as formalized in the form of legislation. How Islamic law regulates the procedures for carrying out the five daily prayers, fasting and the other rules does not require positive legal rules. That the five daily prayers are obligatory or fardhu 'ain according to Islamic law, is not a state matter. The state cannot intervene, and also bargains so that the five daily prayers become the sunnah of mu'akad for example. Islamic law in this field directly applies without being able to be intervened by state power. The thing needed is a rule that can give Muslims the freedom to carry out the laws of worship, or at most are the aspects of state administrative law to facilitate the implementation of an Islamic legal principle.

Take the example in the field of labor law, of course for example, there are rules that provide opportunities for Muslim workers to perform Friday prayers. Likewise, in the field of hajj and zakat, there is a need for legislation to govern the organization of the hajj pilgrims, zakat administration, and so on. Such an arrangement is closely related to the function of the state which must provide services to its people. Such an arrangement is also associated with our state philosophy, which rejects the principle of "separation of religious affairs from state affairs" which was confirmed by Professor Soepomo in BPUPKI sessions, when the nation's founders drafted a constitution for an independent state. A year ago, the Government prepared a bill of Law concerning the Applied Law on Religious Courts. This bill is an attempt to transform the rules of Islamic law, as a law that lives in society into positive law. Its scope is the legal fields which are the authority of the Religious Courts. Of course, the legal subject of this positive law will apply specifically to Muslim citizens, or who voluntarily submit themselves to Islamic law. The President and the Parliament have also ratified the Law on Waqf, which transforms the rules of Islamic law into positive law. Various laws related to business law have also provided an appropriate place for the rules of Islamic law relating to banking and insurance.

\section{The Position of Sharia Science in Legislation}

The position of sharia science in legislation lies in its position as a core value in various laws and regulations, which is not outlined in the form of formalizing Islamic sharia. Rather, it is outlined in the form of values that exist in the legislation itself. In its implementation, the essential thing is how the sharia sciences become the body of legislation, with due regard to the norms that exist in sharia. In other words, which are included in the legal domain and which are included in the sharia domain that can be applied in the life of the nation and state. Thus the role and contribution of sharia sciences as well as sharia scholars can influence the advancement of law in Indonesia. ${ }^{32}$ This indicates the very influential position of sharia science for Indonesian people.

Ratification of sharia-based regional regulations is indeed different from the ratification of laws which contain sharia values. Ratification of laws with a sharia nuance relatively did not cause national debate about the position of Islam or Islamic sharia in the regulatory system in Indonesia. ${ }^{33}$ Whereas the ratification of sharia-based regional regulations created a lot of very significant debates, especially from academics, observers, social-political activists and human rights. ${ }^{34}$ They considered the application of sharia regulations in the regions to ignore aspects of human rights that the State should protect the lives of its citizens ${ }^{35}$.

Critical voices about the formalization and legislation of Islamic law in Aceh and other regions can be categorized into five groups.First, criticism comes from people who fear that Islamic law is not implemented in kaffah manner, in the sense of not regulating all aspects of life. Second, the

${ }^{32}$ Ismail Hasani and A. Gani Abdullah, Pengantar IImu Perundang-Undangan..., 2006.

${ }^{33}$ Muhammad Julijanto, “Implentasi Hukum Islam..., pp. 66-85.

${ }^{34}$ Bahtiar Effendi, "Duduk Soal Perda Syariah," Gusdur Net, 2008, http://www.gusdur.net/id/mengagas-gus-dur/duduksoal-perda-syariah-2.

35 Dalmeri, "Prospek Demokrasi: Dilema Antara Penerapan Syariat Islam Dan Penegakan Hak Asasi Manusia Di Indonesia," Salam Jurnal Studi Masyarakat Islam, vol. 15, no. 2 (2012), pp. 228-39, http://download.portalgaruda.org/article.php?article=979 59\&val=276\&title=Prospek Demokrasi: Dilema antara Penerapan Syariat Islam dan Penegakan Hak Asasi Manusia di Indonesia." 
opposite of the first, their criticism is based on fear that the sharia will be implemented as a whole. According to them, if the sharia is in the form of Islamic law which has been written in classic books or interpreted by some authorities, it will cause some problems for the community. Third, those who criticize the efforts to formalize and legalize sharia, especially in Aceh. According to them, these efforts are not in line with the wishes of the Acehnese people about sharia and do not have a significant impact on solving problems in Aceh. Fourth, those who question the relationship between shari'a legislation and the needs of the Indonesian population for good governance, civil society and democracy. Fifth, those who question the synchronization between sharia legislation or sharia regulations and national legal system. ${ }^{36}$

Pros and cons to the regional regulations that transform sharia not only occur in society, but also in parliament. Around 56 members of the People's Representative Council (DPR) from a number of factions collected signatures to reject these regional regulations. By viewing that some members of the council performed such behavior, around 134 other council members made a rival and expressed their agreement on the regional regulations that adopted sharia. ${ }^{37}$

According to Masykuri Abdillah, three groups in Indonesia have different attitudes and views on the discourse of the implementation of Islamic sharia. First, group-oriented towards making Islam as an ideology. The group always strives to fight for the implementation of Islamic teachings comprehensively (kaffah), namely aqeedah, sharia and moral ethics. Second, group-oriented to Islam as a source of ethics and morals. This group is only trying to fight for the implementation of faith and morals. This group is supported by those whose national insight is more dominant than their Islamic insight. Third, a group that fights for the implementation of sharia wherever possible - besides faith and moral ethics - that is integrated into the national system. In short, according to him, the first orientation is to bring Islam an ideology, the second orientation is to bring Islam a source

${ }^{36}$ Nurrohman, Islamic Thought in Indonesia's Religio Political Context, (Bandung: Penerbit Gunung Djati Press Bandung, 2010).

37 Muntasir Syukri, "No TitleTransformasi Syariat Islam Di Indonesia,” 2011, https://muntasirsyukri.wordpress. com/2011/09/01/transformasi-syariat-islam-di-indonesia/. of faith and moral ethics, and the third orientation is to bring Islam as a sub-ideology..$^{38}$

\section{Conclusions}

Sharia theoretically and practically is being a part and source in the formulation of laws and regulations since it is considered capable of underlying and directing the dynamics of Indonesian society in achieving its goals. It contains dimensions rooted in the text of the nash qath'i which is universal and valid throughout the ages, besides it also includes dimensions rooted in the text of nashdzanni as the area of ijtihâd and is adaptive to the times. Moreover, there are four types of Islamic law reform products in Indonesia, namely: figh, fatwa, court products, and legislation. The big theme of the discourse of renewing Islamic legal thinking is sourced from the term ijtihâd, which the current ijtihâd movement shows a variety of methods and tendencies in the Indonesian context.

The position of sharia knowledge in legislation lies in its position as a core value in various laws and regulations, which is not stated in the formalization of Islamic sharia. The important thing to note is how the sharia become the body of laws and regulations, by constantly taking into account the norms in the sharia, which is the legal and sharia domain. Thus resistance to the role and contribution of the sharia sciences including sharia scholars can be avoided.

\section{References}

Ahmas, Khalilullah, "Hukum Islam Dalam Ketatanegaraan (Telaah Perspektif Menuju Indonesia Baru), " Jurnal Al-Syirah, vol. 1, no. 2, 2003. Aiman, "Kedudukan Ilmu Syariah Dalam PerundangUndangan," Aiman selalu berbagi, 2013. http://mamduhhakim.blogspot.com/2013/10/ kedudukan-ilmu-syariah-dalam-perundang.html. Ali, Mohammad Daud, Hukum Islam PIH Dan THI Di Indonesia, Jakarta: PT Raja Grafindo Persada, 1996.

_- Pengantar Ilmu Hukum Dan Tatata Hukum Islam Di Indonesia, Jakarta: PT Raja Grafindo Persada, 2007.

${ }^{38}$ Labib Muttaqin, "Positifisasi Hukum Islam Dan Formalisasi Syari'Ah Ditinjau Dari Teori Otoritarianisme Khaled Abou El-Fadl," Al-Ihkam: Jurnal Hukum \& Pranata Sosial 11, no. 1 (2016), p. 67, https://doi.org/10.19105/al-ihkam.v1111.859. 
Arkoun, Mohammed, The Concept of Authority in Islamic Thought: La Hukna Illa Li-Llah, New York: Institute of Political science, 1984.

Auf, Yussef, "Islam and Sharia Law Historical, Constitutional, and Political Context in Egypt." Atlantic Council, no. 03, 2016.

Bodenheimer, Edgar, Jurisprudence: The Philosophy and Method of the Law, Cambridge: Harvard University Press, 1967.

Buzama, Khoiruddin. "Pemberlakuan TeoriTeoriHukum Islam Di Indonesia, " AL-'ADALAH, vol. X, no. 4, 2012.

Dalmeri, "Prospek Demokrasi: Dilema Antara Penerapan Syariat Islam Dan Penegakan Hak Asasi Manusia Di Indonesia." Salam Jurnal Studi Masyarakat Islam, vol. 15, no. 2, 2012. http:// download.portalgaruda.org/article.php?articl e=97959\&val=276\&title=Prospek Demokrasi: Dilema antara Penerapan Syariat Islam dan Penegakan Hak Asasi Manusia di Indonesia.

Daud, Muhammad, "Kedudukan Hukum Islam Dalam Sistem Hukum Indonesia, " Jurnal Hukum \& Pembangunan, vol. 12, no. 02, 1982.

Diab, Ashadi L, "Dinamika Pekiran Hukum Islam Di Indonesia Dan Tantangannya, " Jurnal Al'Adl, vol. 8, no. 2, 2015.

Effendi, Bahtiar, "Duduk Soal Perda Syariah." Gusdur Net, 2008. http://www.gusdur.net/id/ mengagas-gus-dur/duduk-soal-perda-syariah-2.

_- Islam Dan Negara: Transformasi Pemikiran Dan Praktik Politik Islam Di Indonesia. Jakarta: Paramadina, 1998.

Fauzan, "Progressive Law Paradigm in Islamic Family Law Renewal in Indonesia." Jurnal Ilmiah Mizani: Wacana Hukum, Ekonomi Dan Keagamaan, vol. 7, no. 2, 2020. https://doi. org/10.29300/mzn.v7i2.3617

Hasani, Ismail, and A. Gani Abdullah, Pengantar Ilmu Perundang-Undangan, Jakarta: . Fakultas Syar'ah dan Hukum UIN Syarif Hidayatullah, 2006.

Huda, Nurul, and Mohamad Heykal, Lembaga Keuangan Islam Tinjauan Teoritis Dan Praktis, Jakarta: Kencana, 2010.

Julijanto, Muhammad, "Implentasi Hukum Islam Di Indonesia Sebuah Perjuangan Politik Konstitusionalisme." In Annual International Conference Islamic Studies (AICIS XXI), 666-85, 2012. http://www.republika.co.id/berita/duniaislam/islam-mancanegara/12/05/09/m3qcqk-2030-. Mardani, "Hukum Islam Dalam Sistem Hukum Nasional." Jurnal Hukum \& Pembangunan, vol.
38, no. 2, 2008. https://doi.org/10.21143/jhp. vol38.no2.170.

Masruhan, "Positivisasi Hukum Islam Di Indonesia." The Indonesian Journal of Islamic Family Law, vol. 01, no. 02, 2011. https://doi.org/10.20885/ unisia.vol26.iss48.art11.

Muhtarom, $M$, “Kedudukan Peraturan PerundangUndangan Negara Dalam Institusi Hukum Islam." Jurnal Suhuf , vol. 27, no. Mei 2015.

Muttaqin, Labib, "Positifisasi Hukum Islam Dan Formalisasi Syari'Ah Ditinjau Dari Teori Otoritarianisme Khaled Abou El-Fadl," Al-Ihkam: Jurnal Hukum \& Pranata Sosial, vol. 11, no. 1, 2016. https://doi.org/10.19105/al-ihkam.v1111.859.

Nafis, Muhammad Wahyuni, and Rahman Zainuddin, Konstektualisasi Ajaran Islam, Jakarta: Ikatan Persaudaraan Haji Indonesia, 1995.

Nurhayati, "Memahami Konsep Syariah, Fikih, Hukum Dan Ushul Fikih," Jurnal Hukum Ekonomi Syariah, vol. 2, no. 2, 2018. https:// doi.org/10.26618/j-hes.v2i2.1620.

Nurrohman, Islamic Thought in Indonesia's Religio Political Context, Bandung: Penerbit Gunung Djati Press Bandung, 2010.

Praja, Juhaya S, Filsafat Hukum Islam. Bandung: Pusat Penerbitan Universitas LPPM Universitas Islam Bandung, 1995.

Rosadi, Aden, Peradilan Agama Di Indonesia : Teori Dan Sistem Pembentukan. Bandung: Simbiosa Reka Utama, 2015.

Sarifin, Pipin, and Dedah Jubaedah, Ilmu PerundangUndangan, Bandung: Pustaka Setia, 2012.

Schirrmacher, Christine. The Sharia - Law and Order In. Germany: Hänssler Verlag, 2013.

Sularno, M, "Syari'at Islam Dan Upaya Pembentukan Hukum Positif Di Indonesia, " Al-Mawarid, vol. 14, no. 2, 2006.

Syukri, Muntasir, "No Title Transformasi Syariat Islam Di Indonesia," 2011. https:// muntasirsyukri.wordpress.com/2011/09/01/ transformasi-syariat-islam-di-indonesia/.

Umar, Nasarudin, “Konsep Hukum Modern: Suatu Perspektif Keindonesiaan, Integrasi Sistem Hukum Agama Dan Sistem Hukum Nasional." Walisongo: Jurnal Penelitian Sosial Keagamaan, vol. 22, no. 1, 2014. https://doi.org/10.21580/ ws.2014.22.1.263.

Utama, Sopyan Mei, "Eksistensi Hukum Islam Dalam Peraturan Perundang-Undangan Di Indonesia." Jurnal Wawasan Yuridika, vol. 2, no. 1, 2018. https://doi.org/10.25072/jwy.v2i1.166. 